\title{
MENINGKATKAN KEMAMPUAN SISWA DALAM BERETIKA MELALUI PEMBUATAN FILM PENDEK (STUDI EKSPERIMEN SEMU DI SMAN 1 TUNGKAL ILIR)
}

\author{
Zuli Febriati $^{1}$, Evia Darmawani ${ }^{2}$ dan Ahmad Rofi Suryahadikusumah ${ }^{3}$ \\ Universitas PGRI Palembang ${ }^{1}$ \\ Email: Zulifebriyati2@gmail.com \\ Universitas PGRI Palembang ${ }^{2}$ \\ Email: evia.syamsuddin@gmail.com \\ Universitas PGRI Palembang ${ }^{3}$ \\ Email:rofi3003@gmail.com
}

\begin{abstract}
ABSTRAK
Kemampuan berperilaku etis siswa saat ini mengalami penurunan yang ditandai dengan seringnya membuat gaduh di kelas sehingga mengganggu kelas yang lain. Tujuan penelitian ini untuk mengetahui apakah pembuatan film pendek dapat mempengaruhi perilaku siswa dalam beretika di Sekolah Mengah Atas Negeri 1 Tungkal Ilir.Penelitian ini menggunakan penelitian kuantitatif dengan metode pre-experimental design one-group pre-test-post-test design. Sampel penelitian siswa kelas XI IPS 1 yang berjumlah 25 siswa. Hasil penelitian menunjukkan pembuatan film pendek efektif untuk meningkatkan perilaku etis siswa, dilihat dari analisis data statistik didapat bahwa berdasarkan hasil perhitungan uji-t dengan taraf signifikan ( $\alpha$ ) 0,05 dan $d k=25-1=24$ didapatkan nilai $t_{\text {hitung }}=8,3172$. Penelitian membuktikan dengan membuat film pendek siswa menyadari dan memahami baik buruknya perilaku. Pembuatan film pendek ini dapat dijadikan media bagi pelayanan bimbingan klasikal di kelas lain.
\end{abstract}

\section{Kata Kunci: Kemampuan Beretika, Film Pendek}

\section{IMPROVING STUDENT'S ETHICAL BEHAVIOR THROUGH MAKING SHORT FILM (QUASI EXPERIMENTAL STUDIES AT SMAN 1 TUNGKAI ILIR)}

\begin{abstract}
Student's ability to behave ethically currently being decreased, they making noise in classroom so that interfere with other classes. Aim of study was to know whether the making of a short film can improving they ethical behavior. This research using quantitative research method pre-experimental design one-grouppre test-post test design. Research use 25 students as a sample. Results showed that by making a short films is effective to enhance students 'ethical behavior, based on results of $t$ - test with level significant $(\alpha)=0.05$ and $d k=24 t_{\text {hitung }}=$ 8.3172. Research proves with the short film making students realize and understand the good the bad behavior. The making of this short film can be used as a medium for guidance service in classical setting in other classes.
\end{abstract}

Keywords: Ethical Behavior, Short Film 


\section{PENDAHULUAN}

Perilaku etis merupakn perilaku yang didasari oleh kesesuaian dengan aturan dan norma-norma yang berlaku secara umum, baik di sekolah maupun dimasyarakat. Dapat diartikan perilaku etis berkaitan juga dengan moralitas seseorang. Maka dari itu untuk membentuk perilaku etis pada siswa, setiap jenjang sekolah selalu menanamkan nilai-nilai etis dengan berbagai cara mulai dari dibuatnya peraturan sekolah maupun strategi untuk membina dan menanamkan sikap dan perilaku etis. Ini bertujuan untuk penyesuaian tingkah laku siswa dalam menyikapi aturan sekolah dengan baik.

Berprilaku secara etis menjadi ukuran bagi remaja untuk mencapai perkembangan moral. Umumnya siswa SMU berada pada tahap perkembangan moralitas konvensioanal, orientasi dalam berprilaku ialah hukuman dan ketertiban, dan pada tahap menyesuaikan diri untuk menghindari penilaian oleh otoritas resmi dan rasa bersalah (Hurlock, 2012). Sementara itu, perilaku etis menunjukkan sikap baik atau buruk yang sangat personal. Oleh karena itu pengembangan perilaku etis pada siswa SMU harus diarahkan pada pemahaman terhadap baik buruknya sebuah perliaku bagi dirinya, bukan sekedar memberikan hukuman atau ganjaran pada perilaku keliru, sehingga dapat menstimulasi perkembangan moralitas pada tahap konventional yang berarti orientasinya dampak bagi diri dan lingkungan.

Hasil temuan peneliti di Sekolah Menengah Atas Negeri 1 Tungkal Ilir belum semua siswa dapat berperilaku etis, masih saja terdapat siswa-siswa yang memiliki perilaku yang tidak sesuai dengan nilai-nilai yang berlaku. Salah satunya siswa membuat kegaduhan di dalam kelas saat tidak ada guru. Hal ini berdampak pada lingkungan sekitarnya seperti mengganggu kelas lain serta berdampak pada dirinya sendiri, karena saat ia ditegur oleh orang lain ia akan merasa tidak enak, padahal jelas perilakunya bertentangan dengan aturan.

Salah satu upaya untuk membantu dan mengedukasi siswa tentang perilaku etis ialah menggunakan pembuatan film pendek yang berupa dokumenter keseharian siswa. Heinichi (Puspitasari, 2014) film dokumenter merupakan film yang dibuat berdasarkan fakta, serta pola penting dalam film dokumenter menggambarkan permasalahan suatu kehidupan manusia yang meliputi bidang 
ekonomi, budaya, hubungan antar manusia, etika dan lain sebagainya. Keseharian siswa dalam beretika di sekolah diharapkan dapat menjadi media bagi siswa untuk menggali nilai - nilai etis yang ada di sekitar mereka.

Pembuatan film pendek membuat siswa bertemu secara langsung dengan kondisi bermasalah yang merangsang mereka untuk mempertanyakan mengapa sampai terjadi masalah, bagaimana hal ini terjadi, dan apa akibatnya. Film pendek akan membuat perasaan, tindakan dan cara pikir siswa saling terhubung. Pembuatan film pendek merupakan aplikasi dari model pembelajaran berbasis proyek (project based learning), project based learning merupkan pembelajaran dimana siswa melakukan eksplorasi, penilaian, interpretasi, sintesis, dan informasi berdasarkan kondisi nyata di sekitarnya (Mariyaningasih \& Hidayati, 2018).

Pembuatan film pendek dapat dilakukan dalam layanan dasar dengan menggunakan strategi klasikal melalui metode ekspositori. Dalam metode ekspositori guru memberi informasi hanya pada waktu-waktu tertentu yang diperlukan peserta didik. Diharapkan dengan penugasan tersebut dapat membantu siswa terlibat secara langsung untuk menelusuri nilai-nilai etis baik buruk berbagai tindakan sebagai seorang siswa untuk diri mereka sendiri. Termasuk sanksi-sanksi sosial, yaitu bagaimana siswa dapat memahami dan mengalami sanksi sosial, dalam artian siswa dapat melibatkan dampak dari setiap perilaku, bahwa etika bukan hanya sebuah aturan yang harus diikuti tetapi sebuah konsekuensi dari setiap perilaku.

\section{METODE PENELITIAN}

\section{METODE}

Penelitian ini menggunakan penelitian kuantitatif dengan metode preexperimental design dan menggunakan jenis desain penelitian one-group pre-testpost-test design. Peneliti melakukan satu kali pengukuran di depan (pre-test) sebelum adanya perlakuan (treatment), kemudian setelah perlakuan dilakukan pengukuran kembali (post-test) (Noor, 2011). Desain penelitian dapat dilihat pada gambar 1.

\begin{tabular}{|ccc|}
\hline Pre-Test & Variabel Terikat & Post Test \\
$\mathrm{O}_{1}$ & $\mathrm{X}$ & $\mathrm{O}_{2}$ \\
\hline
\end{tabular}

Gambar 1 Desain one-group pre-test-post-test design 


\section{POPULASI DAN SAMPEL}

Populasi dalam penelitian ini adalah keseluruhan siswa kelas XI IPS 1 di Sekolah Menengah Atas Negeri 1 Tungkal Ilir berjumlah 25 siswa. Populasi ini diambil berdasarkan dengan situasi siswa kelas XI IPS 1 yang dianggap memiliki perilaku etis yang rendah ditandai dengan banyaknya siswa yang sering membuat kegaduhan di kelas. Keseluruhan siswa dalam populasi dimasukkan kedalam sampel yang berjumlah 25 siswa.

\section{VARIABEL}

\section{a. Pembuatan Film Pendek}

Pembuatan film pendek adalah suatu tugas yang diberikan oleh peneliti berupa kegiatan yang telah dirancang untuk diperankan dan direkam oleh siswa. Siswa memerankan suatu adegan yang kemudian direkam. Topik yang digunakan dalam pembuatan film pendek ini berkenaan dengan perilaku etis siswa.

\section{b. Kemampuan dalam Beretika}

Kemampuan beretika merupakan sikap individu dalam menjalankan aktivitasnya sesuai dengan nilai-nilai etika atau sesuai dengan norma yang berlaku secara umum. Kemampuan ini diukur menggunakan skala likert, dengan berpatokan pada aspek dan indikator pada tabel 1 .

Tabel 1

Aspek dan Indikator kemampuan beretika

\begin{tabular}{|c|l|}
\hline Aspek & \multicolumn{1}{|c|}{ Indikator } \\
\hline Pengenalan & Mengenal keragaman sumber norma yang berlaku di masyarakat \\
\hline Akomodasi & $\begin{array}{l}\text { Menghargai keragaman sumber norma sebagai rujukan } \\
\text { pengambilan keputusan }\end{array}$ \\
\hline Tindakan & $\begin{array}{l}\text { Berperilaku atas dasar keputusan yang mempertimbangkan aspek- } \\
\text { aspek etis }\end{array}$ \\
\hline
\end{tabular}

\section{PROSEDUR}

Penelitian ini dilakukan sebanyak 6 kali pertemuan, 1 kali pre-test, 4 sesi perlakuan (treatment) dan 1 kali post-test. Sebelum adanya perlakuan diberikan pretest terlebih dahulu untuk mengetahui kemampuan berperilaku etis siswa sebelum adanya perlakuan. Penelitian dilakukan bekerjasama dengan guru seni budaya sebagai mitra. Langkah kerja yang akan dilakukan dalam penelitian ini 
mengikuti langkah kerja pada kegiatan project based learning. Langkah kerja dirinci pada poin - poin di bawah ini.

1. Peneliti melakukan pengamatan awal melalui pengisian angket pre-test

2. Memberikan tiga kali penugasan, yaitu penugasan pertama: Peneliti memberikan tugas membuat film pendek dan siswa mendiskusikan serta menentukan tema film pendek yang akan dibuat. Penugasan kedua: Siswa memulai proses pembuatan film pendek. Penugasan ketiga: Siswa menyelesaikan pembuatan film pendek.

3. Siswa memberikan laporan, yaitu menceritakan film pendek yang telah dibuat, pemikiran, dan perasaan yang muncul selama membuat film pendek.

4. Melakukan evaluasi akhir dengan pemberian angket evaluasi hasil layanan, dan melakukan pengamatan perilaku siswa setelah diberikan perlakuan

5. Pemberian post-test sebagai tes akhir setelah diberikan perlakuan dan melihat perilaku etis siswa setelah diberikan perlakuan tersebut.

\section{HASIL DAN PEMBAHASAN}

Hasil penelitian menunjukkan bahwa tugas membuat film pendek memiliki pengaruh terhadap kemampuan siswa beretika. Berdasarkan hasil perhitungan uji-t dengan taraf signifikan $(\alpha) 0,05 \mathrm{dan} d \mathrm{k}=25-1=24$ didapatkan nilai $\mathrm{t}_{\text {hitung }}=$ 8,3172. Dengan demikian dapat disimpulkan bahwa $t_{\text {hitung }}>t_{\text {tabel }}$ atau 8,3172 $>$ 1,71 maka $\mathrm{H}_{\mathrm{o}}$ ditolak dan $\mathrm{H}_{\mathrm{a}}$ diterima. Yang berarti hipotesis pemberian tugas membuat film pendek memiliki pengaruh terhadap perilaku etis siswa di Sekolah Menengah Atas Negeri 1 Tungkal Ilir diterima kebenarannya. Secara rinci, perbedaan perolehan skor pre-tes dan post - tes disajikan dapat dilihat pada tabel 2.

\section{Tabel 2}

Perolehan skor pre - tes dan post - tes

\begin{tabular}{ccccccc}
\hline Sampel & Pre-test & Post-test & $\begin{array}{c}\mathrm{D} \\
\text { (gain) }\end{array}$ & $\mathrm{d}^{2}$ & $\mathrm{~d}-\mathrm{Md}$ & $\mathrm{x}^{2} \mathrm{~d}$ \\
\hline $\mathbf{1}$ & 75 & 80 & 5 & 25 & $-1,88$ & 3,5344 \\
$\mathbf{2}$ & 72 & 77 & 5 & 25 & $-1,88$ & 3,5344 \\
$\mathbf{3}$ & 80 & 83 & 3 & 9 & $-3,88$ & 15,0544 \\
$\mathbf{4}$ & 79 & 85 & 6 & 36 & $-0,88$ & 0,7744 \\
$\mathbf{5}$ & 81 & 86 & 5 & 25 & $-1,88$ & 3,5344 \\
\hline
\end{tabular}




\begin{tabular}{ccccccc}
\hline $\mathbf{6}$ & 76 & 91 & 15 & 225 & 8,12 & 65,9344 \\
$\mathbf{7}$ & 68 & 74 & 6 & 36 & $-0,88$ & 0,7744 \\
$\mathbf{8}$ & 84 & 90 & 6 & 36 & $-0,88$ & 0,7744 \\
$\mathbf{9}$ & 74 & 79 & 5 & 25 & $-1,88$ & 3,5344 \\
$\mathbf{1 0}$ & 68 & 87 & 19 & 361 & 12,12 & 146,8944 \\
$\mathbf{1 1}$ & 84 & 89 & 5 & 25 & $-1,88$ & 3,5344 \\
$\mathbf{1 2}$ & 75 & 89 & 14 & 196 & 7,12 & 50,6944 \\
$\mathbf{1 3}$ & 81 & 83 & 2 & 4 & $-4,88$ & 23,8144 \\
$\mathbf{1 4}$ & 76 & 80 & 4 & 16 & $-2,88$ & 8,2944 \\
$\mathbf{1 5}$ & 77 & 89 & 12 & 144 & 5,12 & 26,2144 \\
$\mathbf{1 6}$ & 79 & 87 & 8 & 64 & 1,12 & 1,2544 \\
$\mathbf{1 7}$ & 78 & 86 & 8 & 64 & 1,12 & 1,2544 \\
$\mathbf{1 8}$ & 75 & 82 & 7 & 49 & 0,12 & 0,0144 \\
$\mathbf{1 9}$ & 73 & 82 & 9 & 81 & 2,12 & 4,4944 \\
$\mathbf{2 0}$ & 77 & 84 & 7 & 49 & 0,12 & 0,0144 \\
$\mathbf{2 1}$ & 84 & 87 & 3 & 9 & $-3,88$ & 15,0544 \\
$\mathbf{2 2}$ & 84 & 91 & 7 & 49 & 0,12 & 0,0144 \\
$\mathbf{2 3}$ & 72 & 76 & 4 & 16 & $-2,88$ & 8,2944 \\
$\mathbf{2 4}$ & 85 & 88 & 3 & 9 & $-3,88$ & 15,0544 \\
$\mathbf{2 5}$ & 75 & 79 & 4 & 16 & $-2,88$ & 8,2944 \\
\hline$\sum$ & 1932 & 2104 & 172 & 1594 & - & 410,64 \\
\hline
\end{tabular}

Hasil penelitian membuktikan kekuatan film dalam merubah sikap siswa. Media film selain menyajikan informasi dapat mempengaruhi sikap, siswa akan termotivasi kearah yang lebih baik secara bertahap (Arsyad, 2009). Tidak hanya itu saja pesan yang disampaikan dalam film dapat diterima dengan lebih baik dan mudah melalui pengalaman secara langsung dalam mengerjakan tugas pembuatan film pendek.

Perilaku etis berkaitan dengan moral, moral adalah suatu keyakinan tentang benar salah, baik dan buruk, yang sesuai dengan kesepakatan sosial, yang mendasari tindakan atau pemikiran (Ibung, 2009). Perubahan perilaku siswa yang muncul setelah tugas pembuatan film pendek, didasari oleh pengalaman mempertimbangkan dampak yang akan ditimbulkan dari setiap perilaku yang direkam dalam film pendek mereka.

Dampak yang terlihat setelah penelitian secara umum berada pada kategori tinggi, yang berarti siswa mulai berperilaku atas dasar keputusan yang mempertimbangkan aspek-aspek etis. Hal tersebut diketahui berdasarkan sebaran skor hasil post tes yang menunjukkan frekuensi ( $f i$ ) perolehan skor paling banyak terdapat pada kelas 86-88 (sebaran skor post tes dapat dilihat pada gambar 2 di bawah). 


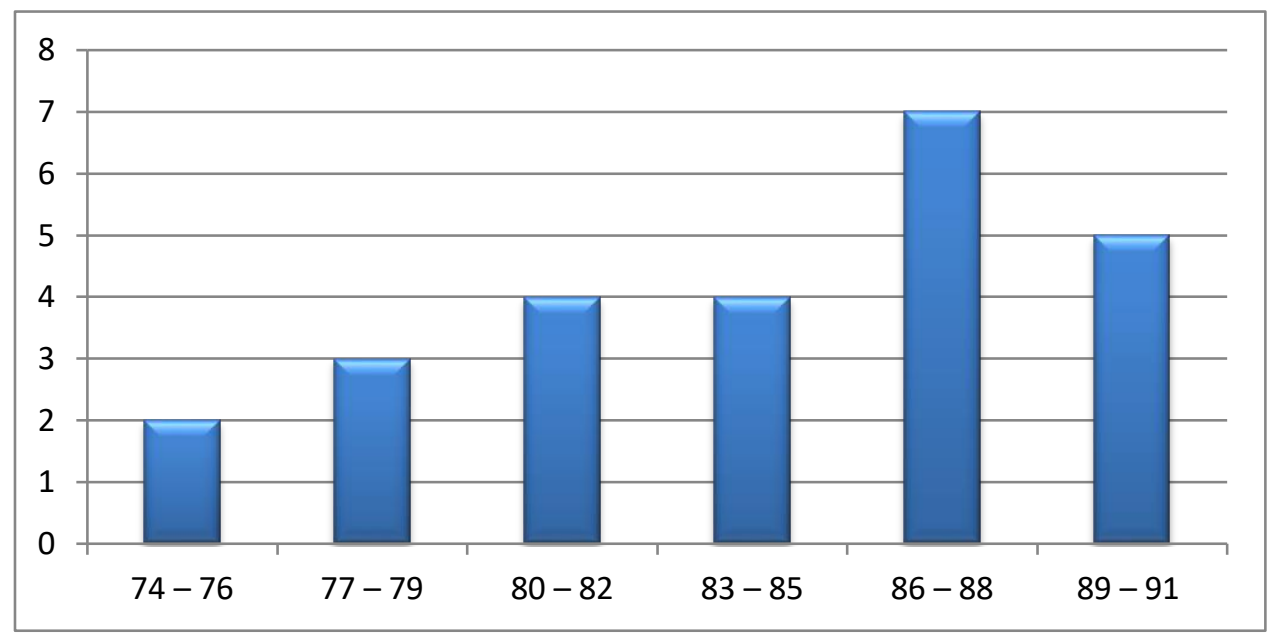

Gambar 2. Diagram Distribusi Frekuensi Nilai Post-test

Berdasarkan hasil penelitian film dapat meningkatkan pemahaman dan kemandirian siswa untuk merubah kondisi dirinya yang semula memiliki etika pergaulan yang kurang baik menjadi lebih baik. Kekuatan film antara lain : 1) sangat bagus untuk menerangkan suatu proses, dan 2) lebih realistis, dapat diulang-ulang dan dihentikan sesuai dengan kebutuhan, dan 3) dapat memberikan kesan yang mendalam yang dapat mempengaruhi sikap siswa (Susilana \& Riyana, 2008).

Pembuatan film dapat dijadikan pengalaman belajar yang bermakna yaitu belajar melalui proses perbuatan atau mengalami sendiri apa yang dipelajari, serta melakukan proses mengamati. Gale (Arsyad, 2009) berpendapat semakin konkret siswa mempelajari bahan pengajaran, contohnya melalui pengalaman langsung, maka semakin banyak pengalaman yang diperolehnya. Sebaliknya semakin abstrak siswa memperoleh pengalaman, maka semakin sedikit pengalaman yang akan diperoleh siswa.

Keberhasilan pembuatan film dalam mengembangkan perilaku dan sikap siswa dalam beretika ialah keterlibatan siswa secara langsung dalam menggali informasi akan konsekwensi dari sebuah perilaku. Hal tersebut sejalan dengan prinsip pengembangan remaja secara positif yang dikemukakan Suryahadikusumah (2016) bahwa remaja dipandang sebagai partisipan bukan penerima informasi, sehingga Positive youth development menekankan kepada 
keterlibatan remaja dan partisipasi aktif dalam proses belajar dan pengembangan diri.

Pengembangan selanjutnya dari penelitian ini dapat dilakukan dengan mengaplikasikan langkah pembuatan film pendek dalam seting bimbingan kelompok. Dalam penelitian ini penugasan diberikan pada satu kelas, sehingga situasi yang dieksplorasi sangatlah terbatas. Penuagasan pembuatan film dalam bimbingan kelompok memberi peluang kepada siswa mengeksplor lebih banyak situasi yang dapat dipilih sebagai fokus sumber norma yang berlaku di berbagai seting kehidupan. Produk film pendek dari setiap kelompok dapat bergiliran dibahas di kelas sehingga menjadi bahan pemodelan yang menarik dalam menginternalisasi kemampuan beretika di berbagai situasi kehidupan, bukan hanya beretika di sekolah saja.

\section{KESIMPULAN}

Film pendek efektif untuk meningkatkan perilaku etis siswa, dilihat dari analisis data statistik didapat bahwa berdasarkan hasil perhitungan uji-t dengan taraf signifikan $(\alpha) 0,05 \mathrm{dan} d \mathrm{dk}=25-1=24$ didapatkan nilai $\mathrm{t}_{\text {hitung }}=8,3172$. Penelitian membuktikan dengan membuat film pendek siswa menyadari dan memahami baik buruknya perilaku. Pembuatan film pendek ini dapat dijadikan media bagi pelayanan bimbingan klasikal di kelas lain.

\section{DAFTAR PUSTAKA}

Arsyad, A. (2009). Media Pembelajaran. Jakarta: Rajawali Pers.

Hurlock, E. B. (2012). Psikologi Perkembangan, Suatu Pendekatan Sepanjang. Rentang Kehidupan (terjemahan). Jakarta: Erlangga.

Ibung, D. (2009). Mengembangkan Nilai Moral Pada Anak. Jakarta: Elex Media Komputindo.

Mariyaningasih, N., \& Hidayati, M. (2018). Bukan Kelas Biasa. Surakarta: Oase Group.

Noor, J. (2011). Metodelogi Penelitian. Jakarta: Kencana Prenada Media Group.

Puspitasari, N. A. (2014). Penggunaan Film Dokumenter Sebagai Media Dalam Meningkatkan Prestasi Belajar Siswa Pada Mata Pelajaran PPKN Di Kelas $\mathrm{X}-\mathrm{Mm}$ SMK Muhammadiyah 5 Kepanjen. Jurnal Pendidikan Kewarganegaraan Universitas Negeri Malang Vol.1, No.1 . 
Suryahadikusumah, A. (2016). Bimbingan Dan Konseling Komunitas Untuk Mendukung Positive Youth Development (Penelitian Tindakan Partisipatoris Bersama Komunitas Schoolzone). Jurnal Penelitian Pendidikan Vol 16 No.2. ISSN : 1412-565X, 137-146.

Susilana, R., \& Riyana, C. (2008). Media pembelajaran: hakikat, pengembangan, pemanfaatan, dan penilaian. Bandung: CV. Wacana Prima. 